\title{
BELAS KASIH \& KEADILAN ALLAH (Kel 34:5-7)
}

\author{
Surip Stanislaus dan Arie R. Oktavianus Saragih*
}

\begin{abstract}
Abstrak
Belaskasih Allah sering dimengerti keliru terutama dalam hubungannya dengan keadilan-Nya. Kalau Allah tetap menghukum setiap kesalahan manusia, lalu di mana belaskasih-Nya? Pewahyuan nama Allah dalam Kel 34:57 mengungkapkan bahwa hakikat Allah adalah belaskasih sekaligus adil. Belaskasih Allah secara eksplisit nyata dalam ungkapan "penyayang dan pengasih, panjang sabar, berlimpah kasih-Nya dan setia-Nya, yang meneguhkan kasih setia-Nya kepada beribu-ribu orang, yang mengampuni kesalahan, pelanggaran dan dosa." Dalam belaskasih itu Allah serentak menyatakan diri-Nya sebagai yang "tidaklah sekali-kali membebaskan orang yang bersalah dari hukuman, yang membalaskan kesalahan bapa kepada anakanaknya dan cucunya, kepada keturunan yang ketiga dan keempat." Tindakan Allah yang tetap menghukum orang yang bersalah adalah perwujudan keadilan-Nya. Belaskasih Allah tidak meniadakan keadilan-Nya. Allah dikatakan adil kalau Ia mengganjar orang yang benar dan menghukum orang yang salah. Ganjaran Allah itu tercurah dalam berkat dan hukuman-Nya dalam kutuk/kemalangan. Namun bagi bangsa Israel, hukuman Allah sering kali bukan semata hukuman demi hukuman, melainkan hukuman itu bertujuan untuk mendidik, menegur dan menyucikan mereka. Dalam hal ini hukuman menjadi sarana karya penyelamatan Allah sehingga tak bertentangan dengan belaskasih-Nya. Oleh karena itu, belaskasih Allah jangan disalahgunakan untuk kompromi terhadap dosa dan melanggar etos Kristiani. Kita harus mengajarkan belaskasih Allah tanpa meniadakan keadilan-Nya, agar belaskasih Allah itu tidak ditafsirkan sebagai pembiaran dan kesempatan bagi manusia untuk berbuat apa saja. Belaskasih Allah harus dipandang sebagai undangan dan kesempatan bagi manusia untuk bertobat demi keselamatannya.
\end{abstract}

Kata-kata kunci : belaskasih, keadilan, ganjaran, hukuman, didikan, teguran, pewahyuan, penyucian, kesempatan, tobat, keselamatan

\footnotetext{
* Surip Stanislaus, lisensiat dalam bidang Theologi; lulusan Universitas Gregoriana, Roma; dosen Kitab Suci pada Fakultas Filsafat Unika St. Thomas, Sumatera Utara; Arie Rizky Oktavianus Saragih, mahasiswa pada Fakultas Filsafat Unika St. Thomas, Sumatera Utara; sedang menjalani TOP (Tahun Orientasi Pastoral) di Keuskupan Agung Medan.
} 


\section{Pengantar}

Tanggal 8 Desember 2015 hingga 20 November 2016 Paus Fransiskus menyelenggarakan Tahun Yubileum Luar Biasa Belaskasih untuk mengundang umat Kristiani mengalami belaskasih Allah. Dunia saat ini perlu menemukan wajah Allah Bapa yang sesungguhnya, yaitu Allah yang berbelaskasih, agar dunia mengerti bahwa sikap menghakimi dan kekerasan bukanlah sikap dan jalan yang tepat untuk menghadapi suatu persoalan. Dalam kalangan internal Gereja pun kebutuhan untuk mengalami wajah Allah yang berbelaskasih menjadi sebuah kebutuhan yang mendesak. Dalam wawancara dengan redaksi majalah mingguan Credere dari Italia, Paus mengakui bahwa tidak jarang Gereja sendiri berbicara dalam bahasa yang keras, bersikap kaku, terlalu sering menekankan norma moral yang malahan meminggirkan orang lain, dan menampakkan sikap penghakiman. Gereja mestinya menjadi tempat belaskasih Allah dikembangkan, sehingga setiap orang merasa diterima, dikasihi, diampuni dan didukung untuk menghayati hidup Injili. ${ }^{1}$

Sungguh disayangkan bahwa belaskasih Allah yang seharusnya menjadi topik sentral teologi pada abad ke-21 ini justru terkesan dikesampingkan. Misalnya dalam teologi moral, pengaruh klasifikasi keutamaan $^{2}$ terlalu besar sehingga tema belaskasih Allah kurang mendapat tempat. Kerap kali tema belaskasih Allah hanya dibahas secara singkat dan Ensiklik tentang belaskasih Allah (Dives in Misericordia = Kaya dalam Kerahimam) dari Paus Yohanes Paulus II pun kurang mendapat sambutan para petugas pastoral. Kenyataan minimnya pembahasan ini dapat menyebabkan gagal paham atau pengertian yang cenderung keliru tentang belaskasih Allah. Hal ini nampak ketika belaskasih Allah itu dihadapkan pada keadilan-Nya. Tidak jarang

\footnotetext{
1 T. Krispurwarna Cahyadi, Kemurahan Hati: Wajah Allab - Kesaksian Gereja (Yogyakarta: Kanisius, 2016), hlm. 10-12; Paus Fransiskus, Seruan Apostolik Evangelii Gaudium (Sukacita Injili), penerjemah F.X. Adi Susanto dan B. Harini Tri Prasasti (Jakarta: Dokumentasi dan Penerangan KWI, 2014), no. 114.

${ }^{2}$ Keutamaan yang dimaksud ialah keutamaan Ilahi dan keutamaan moral. Keutamaan Ilahi terdiri dari iman, harap dan kasih. Sedangkan keutamaan moral terdiri dari keadilan, sikap tahu batas, kearifan dan keberanian. Bdk. P. Go Twan An, "Kerahiman dan Keadilan", dalam Gregorius dan P. Sarbini (eds.), Dosa dan Pengampunan: Pergulatan Manusia dengan Allah (Malang: STFT Widya Sasana, 2016), hlm. 236.
} 
belaskasih Allah dipertentangkan dengan keadilan-Nya dan dijadikan alasan untuk mengurangi bahkan meniadakan keadilan-Nya. ${ }^{3}$

De facto Kitab Suci mengajarkan tentang penyelamatan orang berdosa dan bukan pembenaran dosa atau mengasihi orang berdosa dan membenci dosa. Belaskasih Allah seharusnya tidak disalahgunakan untuk berkompromi terhadap segala dosa. Belaskasih Allah tidak dapat dijadikan alasan untuk melanggar etos Kristiani dan juga bukan sikap acuh tak acuh yang membiarkan segala sesuatunya. Belaskasih yang demikian tentu bertentangan dengan hakekat Allah yang adalah adil. Allah adalah adil bila mengganjar yang baik dan menghukum yang jahat. $^{4}$

Kisah-kisah dalam Kitab Suci sudah sejak awal sejarah keselamatan menyajikan belaskasih Allah. Namun Allah sebagai yang berbelaskasih baru secara eksplisit diwahyukan dalam Kel 34:5-7. Pewahyuan ini terjadi pada momen krusial hubungan Allah dengan bangsa Israel. Allah yang baru saja mengikat perjanjian dengan umatNya Israel dikhianati oleh bangsa itu dengan membuat dan menyembah patung anak lembu emas. Saat itu murka Allah menyala-nyala melawan umat-Nya, tetapi kemudian Ia membarui perjanjian-Nya itu dengan mewahyukan nama-Nya. Dalam pewahyuan itu Allah secara eksplisit menyatakan diri-Nya sebagai yang berbelaskasih dengan ungkapan "penyayang dan pengasih, panjang sabar, berlimpah kasih-Nya dan setiaNya, yang meneguhkan kasih setia-Nya kepada beribu-ribu orang, yang mengampuni kesalahan, pelanggaran dan dosa." Akan tetapi serentak dengan itu Ia menyatakan diri-Nya sebagai yang "tidaklah sekali-kali membebaskan orang yang bersalah dari hukuman, yang membalaskan kesalahan bapa kepada anak-anaknya dan cucunya, kepada keturunan yang ketiga dan keempat." Tindakan Allah yang tidak membebaskan orang yang bersalah dari hukuman ini merupakan perwujudan keadilanNya. Namun menurut Brueggemann justru itulah bukti adanya

\footnotetext{
${ }^{3}$ W. Kasper, Belas Kasih Allah: Dasar Kitab Suci dan Kunci Hidup Kristiani, penerjemah F.X. Hadisumarta (Malang: Karmelindo, 2016), hlm. 26-27; S. Leks, "Kerahiman Allah: Inti Sari Hidup Gereja”, dalam Hidup, 48/69 (29 November 2015), hlm. 13.

4 S. Surip, Tragedi Kemanusiaan. Kejatuhan, Peradaban Jahat, dan Penderitaan Manusia (Yogyakarta: Kanisius, 2008), hlm. 55.
} 
pertentangan dalam diri Allah, yaitu antara belaskasih dan keadilan-Nya. Oleh karena itu, ia membagi pewahyuan nama Allah dalam Kel 34:6-7 menjadi dua bagian yang bertentangan, yakni bagian positif (Kel 34:6-7a) dan bagian negatif (Kel 34:7b-7d). ${ }^{5}$

Apakah belaskasih Allah dan keadilan-Nya memang saling bertentangan? Bagaimana harus dimengerti bahwa Allah itu pada hakekatnya belaskasih sekaligus adil? Sungguhkah Allah berbelaskasih dan pada waktu yang sama juga sungguh adil? Benarkah karena belaskasih-Nya Allah berkenan dengan segala bentuk kejahatan yang dilakukan manusia? Jika tidak, apakah berarti Ia tidak akan memberi pengampunan bagi kesalahan manusia?

\section{Tafsir Kel 34:5-7}

${ }^{5}$ Turunlah TUHAN dalam awan, lalu berdiri di sana dekat Musa serta menyerukan nama TUHAN. ${ }^{6 a}$ Berjalanlah TUHAN lewat dari depannya dan berseru: "6b TUHAN, TUHAN, Allah ${ }^{6 c}$ penyayang dan pengasih, ${ }^{6 \mathrm{c}}$ panjang sabar, ${ }^{6 \mathrm{~d}}$ berlimpah kasih-Nya dan setia-Nya, ${ }^{7 \mathrm{a}} \mathrm{yang}$ meneguhkan kasih setia-Nya kepada beribu-ribu orang, ${ }^{7 b}$ yang mengampuni kesalahan, pelanggaran dan dosa; ${ }^{7}$ tetapi tidaklah sekalikali membebaskan orang yang bersalah dari hukuman, ${ }^{7 \mathrm{~d}}$ yang membalaskan kesalahan bapa kepada anak-anaknya dan cucunya, kepada keturunan yang ketiga dan keempat.

Kel 34:5-7 merupakan satu kesatuan dalam perikop Kel 34 yang mengisahkan penampakan diri Allah lewat pewahyuan nama-Nya. Penampakan diri Allah ini menjadi puncak pemulihan perjanjian antara Allah dan bangsa Israel yang telah rusak, karena bangsa itu melanggar perjanjian dengan membuat dan menyembah patung anak lembu emas (Kel 32). Pelanggaran dan dosa bangsa Israel itu mendorong Allah berencana ingin memusnahkan mereka sebagai wujud keadilan-Nya (Kel 32:10). Musa pun berusaha melakukan penebusan dosa (Kel 32:30) dan atas permohonan Musa akhirnya Allah mewahyukan nama-Nya (Kel

\footnotetext{
${ }^{5}$ W. Brueggemann, Theology of the Old Testament (Minneapolis: Fortress Press, 1997), hlm. 215-217.
} 
34:6-7). Alhasil, perjanjian itu dipulihkan kembali dengan pembaruan perjanjian (Kel 34) dan Kel 33 menjadi jembatan penghubung dengan peran Musa sebagai perantara antara Allah dan bangsa Israel. ${ }^{6}$

\section{${ }^{5}$ Turunlah TUHAN dalam awan, lalu berdiri di sana dekat Musa serta menyerukan nama TUHAN}

Nama erat kaitannya dengan identitas diri. Maka, mengetahui nama TUHAN berarti mengetahui siapa TUHAN itu sesungguhnya dan apa yang diperbuat oleh-Nya. Nama TUHAN yang diwahyukan dalam Kel 34:6-7 menjadi rumusan yang digunakan oleh bangsa Israel untuk menggambarkan siapa TUHAN, Allah mereka. ${ }^{7}$

\section{${ }^{6 a}$ Berjalanlah TUHAN lewat dari depannya dan berseru: TUHAN, TUHAN, Allah}

Allah memulai pewahyuan nama-Nya dengan menyerukan “TUHAN, TUHAN, Allah.” Kata TUHAN (dalam huruf besar semua) adalah terjemahan dari kata Ibrani YHWH yang keberadaan-Nya sebagai Allah yang aktif. ${ }^{8}$ Aktifitas Allah berkaitan dengan pemberian diri-Nya. Allah aktif memberikan diri-Nya dan bangsa Israel wajib menerima Allah

\footnotetext{
${ }^{6}$ B. Childs, Exodus, OTL (London: SCM Press, 1974), hlm. 611; H.J. Pokrifka-Joe, Divine Mercy and Judgement in Exodus 34:6-7 and A Selection of Its Echoes (Skotlandia: University of St. Andrew, 2004), hlm. 79. (Disertasi).

${ }^{7}$ W. Brueggemann, Theology of ..., hlm. 215; R. Clements, The Cambridge Bible Commentary on the New English Bible: Exodus (Cambridge: Cambridge University Press, 1972), hlm. 222; A. Cole, Exodus: An Introduction and Commentary (London: Tyndale Press: 1973), hlm. 228; W. Eichrodt, Theology of the Old Testament, 2 jilid (London: SCM Press, 1961/1967), hlm. 206207.

8 Banyak perdebatan tentang akar kata dan asal-usul nama YHWH. Dengan akar kata hwh artinya "jauh" atau hwh artinya "bernafas", maka YHWH dipikirkan sebagai dewa badai yang menghembuskan angin dan menjatuhkan kilat. Ada pula yang berpendapat bahwa nama YHWH berasal dari kata seru Yâh dengannya dewa itu diseru/dipanggil. Namun dari pewahyuan nama Allah

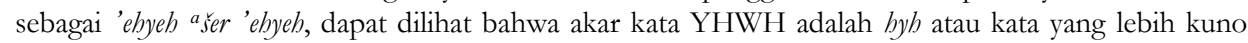
hwh dan dimaknai sebagai "ada". Kata kerja hyh bukan berarti "ada yang statis/pasif" atau "yang secara ontologis ada sejauh berada" (ada sejauh keberadaanya itu tetap, pasti, jelas, tidak diragukan, misalnya setelah menciptakan manusia tinggal diam, menonton saja dan tidak terlibat/campur tangan lagi dalam kehidupan manusia itu). Kata kerja byh artinya "ada yang dinamis/aktif dan relasional", yaitu ada yang keberadaannya berperan aktif, ada yang kehadirannya aktif dalam..., ada yang keberadaannya untuk... YHWH adalah Ada yang keberadaan-Nya berperan aktif untuk memanggilmengutus-menyertai Musa, membebaskan dan menuntun umat-Nya menuju Tanah Terjanji. [Lihat S. Surip, Kitab Taurat Musa: Pengantar dan Tafsir Piliban Kitab Kejadian, Kitab Keluaran, Kitab Imamat, Kitab Bilangan, Kitab Ulangan. Pematangsiantar: [tanpa penerbit], 2017, hlm. 75. (Diktat)].
} 
sebagaimana ada-Nya. Diri Allah itu tidak dapat diajak kompromi untuk berubah hanya agar sesuai dengan keinginan bangsa Israel. ${ }^{9}$

Seruan "TUHAN, TUHAN, Allah" hanya ditemukan pada ayat ini. Durham menyatakan bahwa pengulangan kata TUHAN adalah pengulangan yang disengaja untuk menekankan kehadiran TUHAN dalam keberadaan-Nya yang sesungguhnya. Dengan demikian pewahyuan nama Allah merupakan penyataan siapa TUHAN yang sesungguhnya dan karena itu setiap orang yang mendengarnya wajib merenungkannya dengan sungguh. ${ }^{10}$

\section{${ }^{6 b}$ penyayang dan pengasih}

Sifat TUHAN Allah adalah penyayang (rahûm) dan pengasih ( $w$ hannûn). Kata "penyayang dan pengasih" disebut secara berdampingan hanya jika mengacu pada diri Allah. Namun penyebutan penyayang dan pengasih secara berdampingan membatasi makna dari masing-masing kata penyayang maupun pengasih. Oleh karena itu, kata penyayang dan pengasih perlu dilihat sebagai kata yang berdiri sendiri. ${ }^{11}$

Kata penyayang (rahûm) memiliki akar kata yang sama dengan rahim. Menurut Kamus Besar Bahasa Indonesia, rahim dijelaskan sebagai "kantong selaput dalam perut, tempat janin (bayi), peranakan, kandungan." 12 Selama sekitar sembilan bulan setiap bayi hidup nyaman dan terlindungi dalam rahim ibunya. Seorang bayi hidup dalam rahim yang merangkulnya, melingkari dan menyelimuti. Hidupnya bergantung pada Rahim dan kasih sayang ibu meresap ke dalam bayi itu melalui rahim. Tanpa rahim, seorang bayi tidak akan hidup atau mati. Dengan demikian Allah sebagai penyayang (rahûm) mau menyatakan bahwa Allah itu menghidupkan, menjaga dan memelihara. Bangsa Israel bagaikan dalam Rahim Allah sendiri. ${ }^{13}$

\footnotetext{
${ }^{9}$ J.J. Durham, Exodus, WBC 3 (Waco: Word Books, 1987), hlm. 454.

${ }_{10}$ J.J. Durham, Exodus..., hlm. 454; J.C. Laney, "God's Self-Revelation in Exodus 34:6-8", dalam Bibliotheca Sacra 158 (Januari-Maret 2001), hlm. 41,44.

${ }^{11}$ H.J. Pokrifka-Joe, Divine Mercy..., hlm. 92.

${ }^{12}$ Kamus Besar Bahasa Indonesia Edisi III (Jakarta: Balai Pustaka, 2005), hlm. 923.

${ }^{13}$ W. Brueggemann, Theology of ..., hlm. 216.
} 
Kata pengasih ( $w$ hannûn) menggambarkan sifat kemurahan hati seseorang yang memberi secara gratis bantuan yang ia miliki kepada orang lemah yang membutuhkan. Keputusan untuk memberikan bantuan itu mutlak ada pada si pemberi dan sama sekali tidak tergantung pada kondisi si penerima. Pada umumnya, kata pengasih ( $w$ ḥannûn) ini mengacu pada diri Allah. Dengan mengatakan bahwa Allah adalah pengasih artinya Allah itu pemberi rahmat secara gratis kepada manusia yang membutuhkannya. Keputusan Allah untuk memberikan rahmat-Nya itu tidak tergantung pada kondisi manusia yang akan menerima rahmat itu melainkan mutlak tergantung dari pada-Nya. Oleh karena itu, Allah pengasih berkaitan dengan Allah yang memberikan rahmat-Nya tanpa syarat kepada manusia. $^{14}$

\section{${ }^{6 c}$ panjang sabar}

Sifat Allah adalah panjang sabar ('erek'appayim). Secara etiomologis kata Ibrani erek'appayim adalah sebuah idiom yang berasal dari dua kata yaitu panjang dan hidung. Bagi orang Ibrani hidung erat kaitannya dengan kemarahan. Ketika seseorang marah, wajah dan hidungnya tampak memerah dan terlihat seperti terbakar. Lantaran "hidung Allah" panjang, maka diperlukan waktu yang lama agar sungguh "terbakar". Dengan demikian mau diungkapkan bahwa murka Allah memerlukan waktu yang lama untuk dilampiaskan. ${ }^{15}$

\section{${ }^{6 d}$ berlimpah kasih-Nya dan setia-Nya}

Berlimpah kasih-Nya dan setia-Nya (rab hesed we' met) merupakan atribut TUHAN Allah yang paling sering muncul dalam Perjanjian Lama, yaitu sebanyak 30 kali. Berlimpah kasih-Nya dan setiaNya menjadi rumusan liturgis bangsa Israel yang diucapkan berulangkali untuk menyatakan sifat Allah dalam setiap peribadatan, yaitu dalam pendarasan mazmur-mazmur. Bagi sebagian ahli, ungkapan berlimpah kasih-Nya dan setia-Nya menyatakan satu arti/makna saja. Misalnya, Cassuto berpendapat bahwa ungkapan berlimpah kasih-Nya dan setia-

\footnotetext{
${ }^{14}$ H.J. Pokrifka-Joe, Divine Mercy..., hlm. 93.

${ }^{15}$ W. Brueggemann, Theology of ..., hlm. 216; J.C. Laney, “God's Self-Revelation...", hlm. 46.
} 
Nya sebagai "cinta akan kebenaran" atau "cinta yang sejati dan setia". Ahli lain mengatakan bahwa berlimpah kasih-Nya dan setia-Nya mengacu pada "cinta sejati Allah" atau "cinta setia Allah". 16

Sementara itu pendapat lain yang memandangnya sebagai dua arti/makna mengatakan bahwa ungkapan berlimpah kasih-Nya dan setiaNya menjelaskan dua sifat Allah, yaitu "cinta yang teguh" (hesed) dan "setia" (we'met). Brueggemann menjelaskan hesed sebagai "komitmen yang gigih dalam berelasi, kesiapan dan tekad setia kepada siapa seseorang mengadakan perjanjian". Pengertian ini kemudian dapat dimengerti sebagai "steadfast love", "cinta yang teguh". Hesed Allah mengacu pada komitmen yang sungguh dari Allah terhadap perjanjianNya dengan bangsa Israel. Pada zaman kuno, hesed biasanya digambarkan lewat hubungan perjanjian antara raja dan rakyatnya. Dalam perjanjian antara raja dan rakyatnya, seorang raja terikat kewajiban menunjukkan hesed kepada rakyatnya dan rakyat pun terikat kewajiban untuk membalas hesed rajanya dalam bentuk kesetiaan, pelayanan dan ketaatan. Sebagaimana raja terikat perjanjian dengan rakyatnya, demikian halnya Allah dan bangsa Israel saling terikat perjanjian, yakni Allah berjanji untuk mencurahkan hesed dan bangsa Israel menjanjikan ketaatan dan kesetiaan kepada Allah sebagai balasan atas hesed-Nya. ${ }^{17}$

Tidak semua ahli sependapat dengan pemikiran di atas, karena pengertian mengenai hesed seperti itu terlalu menekankan adanya kewajiban Allah untuk mencurahkan hesed-Nya hanya untuk memenuhi ikatan perjanjian. Oleh karena itu, beberapa ahli berpendapat lain, yaitu hesed justru mau menekankan kebebasan Allah dalam menjalankan belaskasih-Nya. Allah tidak terikat kewajiban apapun dalam mencurahkan belaskasih-Nya. Memang Allah dan bangsa Israel terikat perjanjian, tetapi Allah tetap dalam kebebasan ketika menjalankan hesedNya. Allah sungguh bebas dalam segala tindakan-Nya termasuk dengan

\footnotetext{
16 U. Cassuto, A Commentary on the Book of Exodus (Yerusalem: Magnes Press, 1967), hlm. 440; W. Brueggemann, Theology of ..., hlm. 217; H.J. Stoebe, “hesed”, dalam E. Jenni dan C. Westermann (eds.), Theological of the Old Testament (Massachusetts: Hendrickson Publishers, 1997), hlm. 457; J.C. Laney, "God's Self-Revelation...", hlm. 46.

17 W. Brueggemann, Theology of ..., hlm. 217; H.J. Stoebe, "ḥesed”, hlm. 451; J.C Laney, "God's Self-Revelation...", hlm. 47.
} 
pilihan untuk mengikatkan diri pada bangsa Israel melalui perjanjian. Itulah yang dimaksud dengan berlimpahnya kasih Allah. ${ }^{18}$

Sementara itu makna kata we 'met adalah "kepastian, kebenaran, kesejatian, kesetiaan." Dengan menyatakan bahwa Allah adalah berlimpah setia-Nya ( $r a b$ we'met) berarti bahwa Allah adalah sungguh setia, sejati dan benar. Karena Allah sungguh setia, sejati dan benar, maka setiap sabda-Nya sungguh dapat diimani. Berlimpah kasih-Nya dan setia-Nya adalah suatu hendiadys, yaitu gaya bahasa yang menggunakan dua kata untuk menyatakan satu arti/makna saja. Berlimpah kasih-Nya dan berlimpah setia-Nya sebenarnya saling melengkapi satu sama lain untuk menyatakan satu makna, yaitu bahwa cinta Allah adalah cinta yang sejati. $^{19}$

\section{${ }^{7 a}$ yang meneguhkan kasih setia-Nya kepada beribu-ribu orang}

Bangsa Israel sungguh mengalami belaskasih Allah, karena Allah berlimpah kasih-Nya dan setia-Nya. Kasih setia tersebut ditunjukkan kembali lewat penyataan diri Allah sebagai yang meneguhkan kasih setia-Nya kepada beribu-ribu orang. Ungkapan beribu-ribu orang merujuk pada ribuan keturunan dari bangsa Israel tanpa memandang apakah mereka melakukan perintah-Nya atau tidak. Dengan demikian semakin diteguhkan bahwa kasih setia Allah sungguh tanpa batas. ${ }^{20}$

\section{${ }^{7 b}$ yang mengampuni kesalahan, pelanggaran dan dosa}

Dalam Kel 34:7b pengampunan dosa dihubungkan dengan tiga bentuk dosa dalam Perjanjian Lama, yaitu kesalahan ( $\bar{a} w \bar{o} n)$, pelanggaran ( $p e s ̌ a)$ dan dosa (hațța' $\bar{a})$. Meskipun disebutkan tiga bentuk dosa, namun tujuannya bukan pertama-tama untuk membedakan ketiga dosa itu, tetapi untuk menyatakan bahwa seluruh dosa akan diampuni oleh Allah. Kata mengampuni berarti "membawa, mengangkat atau menanggung." Dalam konteks Kel 34 pernyataan tentang Allah mengampuni kesalahan, pelanggaran dan dosa berarti Allah "membawa, mengangkat,

\footnotetext{
18 J.C. Laney, “God's Self-Revelation...”, hlm. 47.

19 J.C. Laney, “God's Self-Revelation...”, hlm. 47-48.

20 H.J. Pokrifka-Joe, Divine Mercy..., hlm. 103.
} 
menanggung hukuman yang merupakan akibat dosa bangsa Israel saat itu." Kata mengampuni bukan hanya sekadar menyatakan bahwa Allah sungguh mengampuni seluruh dosa bangsa Israel, tetapi juga menyatakan bagaimana Allah mengampuni dosa itu, yaitu Allah sendiri yang membawa, mengangkat dan menanggung hukuman akibat dari dosa bangsa Israel itu. ${ }^{21}$

\section{${ }^{7 c}$ tetapi tidaklah sekali-kali membebaskan orang yang bersalah dari hukuman}

Allah sungguh mengampuni kesalahan bangsa Israel, namun bukan dalam arti bahwa hukumannya pun dihapuskan. Hukuman sebagai akibat dari kesalahan bangsa Israel itu tetap ditimpakan kepada mereka, tetapi dengan pemikiran bahwa hukuman itu sebagai sarana bagi Allah untuk mendidik bangsa Israel agar bertobat. Didikan ini sangat penting demi kelangsungan hubungan Allah dengan bangsa Israel. Hukuman menjadi cara bagi Allah untuk menyucikan bangsa Israel dari kesalahan mereka. Allah memang menginginkan bahwa bangsa Israel menjadi bangsa yang suci sebagaimana Allah sendiri adalah suci. Selain itu hukuman juga merupakan gambaran dari apa yang akan diberikan Allah kepada mereka yang menentang-Nya. Gambaran itu menjadi peringatan bagi orang lain untuk tidak melakukan kesalahan yang sama dan kemudian menjadi inspirasi kepada pertobatan sejati. ${ }^{22}$

Penghukuman Allah juga berkaitan dengan panggilan Allah atas bangsa Israel untuk menjadi bangsa yang kudus dan kerajaan imam bagi bangsa-bangsa lain. Menjadi bangsa yang kudus artinya "bangsa Israel dipisahkan dan dikhususkan dari antara bangsa-bangsa lain.” Sedangkan tugas menjadi kerajaan imam bagi bangsa-bangsa lain maksudnya "bangsa Israel berperan sebagai imam untuk mengurbankan persembahan demi keselamatan bangsa-bangsa lain.” Panggilan dan tugas ini hanya dapat dilakukan jika bangsa Israel setia pada perjanjian dan Allah hadir di

\footnotetext{
${ }^{21}$ U. Cassuto, A Commentary on..., hlm. 440; H.J. Pokrifka-Joe, Divine Mercy..., hlm. 104.

22 W. Houston, "Exodus", dalam J. Barton dan J. Moddiman (eds.), The Oxford Bible Commentary (Oxford: University Press, 2001), hlm. 89; H.J. Pokrifka-Joe, Divine Mercy..., hlm. 104,107,118.
} 
tengah-tengah mereka. Dengan demikian nampak bahwa hukuman Allah semata-mata hanya karena belaskasih-Nya, yaitu demi keselamatan. ${ }^{23}$

\section{7dyang membalaskan kesalahan bapa kepada anak-anak-nya dan cucu-} cucunya, kepada keturunan yang ketiga dan keempat

Beberapa ahli berpendapat bahwa maksud dari ungkapan "membalaskan kesalahan bapa kepada anak-anak-nya dan cucu-cucunya, kepada keturunan yang ketiga dan keempat" adalah penanggungan dosa seorang ayah kepada keturunannya. Dosa seorang ayah yang ditanggungkan kepada keturunannya ini disebut sebagai dosa kolektif. Setiap orang Israel memang saling terikat dan bertanggung jawab satu sama lain, karena mereka semua adalah satu bangsa yang telah mengikat perjanjian dengan Allah. Sebagai satu bangsa maka dosa satu orang akan ditanggungkan kepada yang lainnya. Dengan konsep demikian maka dosa seorang ayah dapat ditanggungkan kepada keturunannya. ${ }^{24}$

Ahli-ahli lain menanggapi: Jika benar bahwa Allah menanggungkan dosa seorang ayah kepada keturunan, maka justru inilah bukti ketidakadilan Allah, yakni Allah memberi hukuman kepada keturunan yang tidak tahu menahu mengenai kesalahan orangtuanya. Melalui Nabi Yehezkiel, dengan jelas Allah telah menentang konsep pembebanan hukuman dosa orangtua kepada anaknya itu. Dengan tegas sang nabi mengatakan: "Orang yang berbuat dosa itu harus mati. Anak tidak akan turut menanggung kesalahan ayahnya dan ayah tidak akan turut menanggung kesalahan anaknya. Orang benar akan menerima berkat kebenarannya, dan kefasikan orang fasik akan tertanggung atasnya" (Yeh 18:20). Dengan demikian ungkapan "membalaskan kesalahan bapa kepada anak-anak-nya dan cucu-cucunya, kepada keturunan yang ketiga dan keempat" bukan menyatakan bahwa dosa seorang ayah ditanggungkan kepada keturunannya. ${ }^{25}$

\footnotetext{
23 E. Botros, The Merciful and Compassionate God: Biblical Theology in An Islamic Context (Hammilton: Mc Master Divinity College, 2013), hlm. 56; H.J. Pokrifka-Joe, Divine Mercy..., hlm. 122; W. Eichrodt, Theology of..., hlm. 428.

${ }^{24}$ H.J. Pokrifka-Joe, Divine Mercy..., hlm. 112

25 J.C. Laney, “God's Self-Revelation...,", hlm. 50.
} 
Beberapa ahli lain pun berbeda pendapat. Ungkapan "yang membalaskan kesalahan bapa kepada anak-anaknya dan cucu-cucunya, kepada keturunan yang ketiga dan keempat" mau menyatakan bahwa Allah akan memberikan hukuman kepada setiap anggota keluarga dari bangsa Israel yang juga telah melakukan dosa karena terpengaruh oleh ayah sebagai kepala keluarga yang lebih dahulu telah melakukan dosa. Pemikiran ini mengingat bahwa pada masa lampau satu komunitas keluarga bisa terdiri dari tiga hingga empat generasi. Kesalahan seorang ayah tentu akan dengan cepat menyebar dan diikuti oleh seluruh anggota keluarganya. Dengan demikian Allah bukannya menghukum keturunan yang ketiga dan keempat karena dosa ayahnya, melainkan karena mereka pun telah turut melakukan dosa yang sama. ${ }^{26}$

Pendapat berbeda lagi mengatakan: Ungkapan "membalaskan kesalahan bapa kepada anak-anak-nya dan cucu-cucunya, kepada keturunan yang ketiga dan keempat" mau menyatakan bahwa seorang anak akan mengalami konsekuensi dari hukuman yang ditanggung ayahnya akibat dosa ayahnya itu. Yang ditanggung anak bukan hukuman akibat dosa sang ayah, tetapi konsekuensi dari hukuman yang ditanggung ayahnya. Misalnya, seorang anak tentu akan mengalami kesedihan sebagai konsekuensi dari pemenjaraan ayahnya karena pelanggaran yang dibuat oleh ayahnya itu. ${ }^{27}$

Masih ada pendapat lain lagi yang menyatakan bahwa penanggungan dosa seorang ayah kepada keturunannya yang ketiga dan keempat mau menyatakan tentang Allah yang memberikan waktu kepada seorang pendosa untuk bertobat dan menyesal. Artinya, Allah tidak serta merta memberikan hukuman kepada seseorang pada saat melakukan dosa. Pernyataan ini juga terbuka pada kemungkinan bahwa Allah tidak jadi memberikan hukuman-Nya jika pada waktu itu pendosa tersebut bertobat. $^{28}$

\footnotetext{
${ }^{26}$ H.J. Pokrifka-Joe, Divine Mercy..., hlm. 110.

27 J.C. Laney, "God's Self-Revelation...", hlm. 50-51.

${ }^{28}$ H.J. Pokrifka-Joe, Divine Mercy..., hlm. 114.
} 
Banyaknya pendapat mengenai arti "yang membalaskan kesalahan bapa kepada anak-anaknya dan cucu-cucunya, kepada keturunan yang ketiga dan keempat" menunjukkan bahwa ungkapan tersebut memiliki makna teologis yang sangat kaya. Namun dari berbagai pendapat itu dapat ditemukan satu benang merah yang menekankan betapa besarnya belaskasih Allah. Terlepas dari apakah makna "keturunan yang ketiga dan keempat" mengacu pada dosa kolektif atau tidak, ungkapan tersebut sesungguhnya menyatakan bahwa belaskasih Allah begitu besar dan tidak terbatas. Hal ini nampak jelas ketika keturunan yang ketiga dan keempat diperbandingkan dengan beribu-ribu orang yang akan mendapatkan belaskasih Allah. Perbedaan signifikan antara sikap Allah "yang membalaskan kesalahan kepada generasi ketiga dan keempat" dengan "yang meneguhkan kasih setia-Nya kepada ribuan orang" justru menunjukkan bahwa belaskasih Allah jauh lebih besar ketimbang kemurkaan dan hukuman-Nya. ${ }^{29}$

\section{Refleksi Teologis Kel 34:5-7}

\section{Belaskasih sebagai Hakikat Allah}

Kel 34:5-7 mengisahkan penampakan Allah yang mewahyukan nama-Nya kepada Musa. Dengan mewahyukan nama-Nya, Allah telah menyatakan siapa diri-Nya sesungguhnya yang sebelumnya tersembunyi bagi manusia. Memang bagi bangsa Israel, nama bukan sekadar sebutan, panggilan atau tanda pengenal, tetapi nama menyatakan sifat, karakter atau kepribadian yang memilikinya. Oleh karena itu, pewahyuan nama Allah merupakan tanggapan-Nya atas permintaan Musa agar dapat mengalami Allah secara pribadi atau mengalami siapa Allah yang sesungguhnya (Kel 33:13). Dengan pewahyuan nama-Nya itu Allah telah menyatakan hakikat diri-Nya yang sesungguhnya, yakni belaskasih. ${ }^{30}$

\footnotetext{
${ }^{29}$ U. Casuto, A Commentary on..., hlm. 440.

${ }^{30}$ W. Fields, Exploring Exodus (Missouri: College Press, 1976), hlm. 743; A. Cole, Exodus..., hlm. 228; R. Clements, The Cambridge Bible..., hlm. 221-222; J.C. Laney, "God's SelfRevelation...", hlm. 40; S. Surip, Kata-kata Hikmat Berahmat (Yogyakarta: Kanisius, 2011), hlm. 71; H.J. Pokrifka-Joe, Divine Mercy..., hlm. 123.
} 
Ketika Allah mewahyukan nama-Nya, Allah tidak sekedar menyatakan diri-Nya dalam bentuk kata-kata, tetapi Ia telah mulai bertindak menyatakan diri-Nya sesuai dengan apa yang dikatakan-Nya. Dengan demikian pewahyuan nama-Nya pada Kel 34:5-7 sesungguhnya bukan sekedar penyatakan diri Allah dalam bentuk kata-kata sebagai Allah yang berbelaskasih, tetapi moment di mana Allah mulai melakukan apa yang dikatakan-Nya, yakni karena belaskasih-Nya Ia telah mengampuni dan membarui perjanjian-Nya dengan bangsa Israel. ${ }^{31}$

Belaskasih sebagai hakikat Allah seperti diwahyukan dalam Kel 34:5-7 sebenarnya sudah dinyatakan sejak awal sejarah keselamatan. Belaskasih Allah menjadi awal mula sejarah dunia dan sejarah keselamatan yang kekal. Kitab Suci adalah kisah tentang belaskasih Allah yang menyelamatkan itu. Kisah dimulai dengan Kej 1-11 tentang penciptaan alam semesta yang karena belaskasih-Nya Allah menciptakan segala sesuatu baik adanya. Ketika manusia pertama jatuh ke dalam dosa, Allah pun tetap berbelaskasih. Allah memberi pakaian, sehingga mereka dapat melindungi diri dari kekerasan alam, menutupi rasa malu satu sama lain dan memelihara martabat mereka. Ketika Kain membunuh Habel, Allah murka kepadanya tetapi Ia tetap berbelaskasih dengan mengancam pembalasan bagi setiap orang yang memukulnya. Allah memberi tanda di dahi Kain sebagai simbol belaskasih Allah yang tetap melindunginya dari ancaman pembunuhan. Demikian halnya meskipun Allah murka dengan mengadakan Air Bah, namun belaskasih-Nya tetap nyata dalam tindakan yang menyelamatkan keluarga Nuh dan menjanjikan bahwa tidak akan ada lagi bencana Air Bah. Selanjutnya mulai dengan Kej 12, belaskasih Allah dinyatakan dalam sejarah bangsa Israel lewat perjanjian antara Allah dan Abraham. Demikianlah belaskasih Allah berlangsung secara nyata sejak awal sejarah keselamatan. ${ }^{32}$

\footnotetext{
${ }^{31}$ C. Barth, Theologia Perjanjian Lama 1 (Jakarta: BPK Gunung Mulia, 2015), hlm. 225.

32 Deden, Pertjikan Alkitab: Tjinta Kasih Allah, penerjemah I. Sutardja (Ende: Flores, 1969), hlm. 12; Paus Fransiskus, Surat Apostolik Paus Fransiskus pada Penutupan Yubileum Luar Biasa Kerahiman Misericordia et Misera (Belaskasih dan Penderitaan), penerjemah F.X. Adi Susanto (Jakarta: Dokumentasi dan Penerangan KWI, 2017), no.7. Selanjutnya dokumen ini disingkat dengan MM diikuti nomor; S. Surip, Tragedi Kemanusiaan..., hlm. 32 bdk. J. Hadianto, "Tanda Pada Sang Pembunuh", dalam Wacana Biblika, 3/12 (Juli-September 2012), hlm. 133; S. Surip, Kitab Taurat..., hlm. 56; W. Kasper, Belas Kasih..., hlm. 76.
} 
Karena belaskasih-Nya pula Allah telah memilih bangsa Israel sebagai bangsa pilihan-Nya. Di tengah situasi bangsa Israel yang tanpa harapan lantaran penindasan dan perbudakan di tanah Mesir, Allah untuk pertama kalinya mewahyukan nama-Nya dan menyatakan bahwa Ia telah mendengarkan teriakan minta tolong dan penderitaan umat-Nya. Maka, karena belaskasih-Nya Allah membebaskan bangsa Israel keluar dari Mesir. Ketika bangsa Israel mengkhianati-Nya dengan tidak setia kepada perjanjian yang telah diikat-Nya di gunung Sinai pun Allah masih tetap mencurahkan belaskasih-Nya dengan mengampuni mereka dan membarui perjanjian antara diri-Nya dan bangsa itu. ${ }^{33}$

Kitab Hosea dengan sangat indah menggambarkan bagaimana belaskasih Allah itu tetap tercurah bagi bangsa Israel meskipun bangsa itu berulangkali melanggar perjanjian dengan Allah. Allah sedemikian berbelaskasih kepada Israel sebagaimana digambarkan dengan tindakanNya menikahi bangsa yang diibaratkan wanita sundal itu. Selain itu buku Hosea pun menggambarkan belaskasih Allah dengan tindakan seorang ayah yang tetap mencintai anaknya yang durhaka. Di kala bangsa Israel mengkhianati-Nya, Allah justru mencurahkan belaskasih-Nya dengan menyatakan: "Hati-Ku berbalik dalam diri-Ku, belaskasih-Ku bangkit serentak" (Hos 11:8). Karena belaskasih-Nya itu Allah telah memutuskan untuk tidak melaksanakan kemurkaan-Nya yang berkobarkobar. $^{34}$

Dari Kel 34:6-7 bangsa Israel merumuskan bahwa pada hakikatnya Allah adalah yang berbelaskasih. Rumusan ini menjadi pegangan utama bangsa Israel sebagai bangsa pilihan Allah. Belaskasih Allah disebut, diingat, dicatat dan dimuliakan bangsa itu sepanjang masa. Pengakuan itu diulang-ulang dalam seluruh Perjanjian Lama, bahkan tidak ada pengakuan yang diulangi sedemikian sering seperti itu. Dari antara 150 mazmur terdapat 55 mazmur yang secara khusus memuji belaskasih Allah. Secara khusus Mazmur 135 menjadikan sifat Allah dalam Kel 34:6 yang "kekal abadi kasih setianya" sebagai refren yang

\footnotetext{
${ }^{33}$ Deden, Pertjikan Alkitab..., hlm. 16; W. Kasper, Belas Kasih..., hlm. 81.

${ }^{34}$ S. Tano Simamora, Bibel: Warisan Iman Sejarah dan Budaya (Jakarta: Obor, 2014), hlm. 151; W. Kasper, Belas Kasih..., hlm. 83.
} 
disebutkan berulang-ulang. Dengan mengulang-ulang rumusan tersebut bangsa Israel diingatkan agar mengandalkan belaskasih Allah tatkala mereka sadar telah mengecewakan Allah karena menyimpang dari jalan yang telah ditetapkan-Nya. ${ }^{35}$

Dalam hakikat-Nya yang adalah belaskasih, Allah menunjukkan keberpihakan-Nya kepada kehidupan manusia, yakni tidak mendatangkan kematian bagi bangsa Israel yang telah berkhianat kepada-Nya dengan membuat dan menyembah patung anak lembu emas. Dengan belaskasihNya itu Allah meneguhkan kembali hidup manusia yang hancur karena dosa, sehingga Allah bukanlah musuh kehidupan, tetapi belaskasih-Nya menjadi sumber kehidupan. Keberpihakan belaskasih Allah kepada kehidupan itu nampak dalam perhatian-Nya secara khusus kepada kaum miskin dan lemah sebagaimana Ia telah membebaskan bangsa Israel dari perbudakan di tanah Mesir. Di Tanah Terjanji pun Allah menegaskan perintah-Nya agar tidak menindas orang miskin, janda dan yatim piatu. Ia juga memberikan perintah agar bangsa Israel menyediakan hari istirahat bagi para budak dan orang asing. Allah menetapkan perayaan Tahun Sabat dan Tahun Yobel dalam rangka solidaritas kepada yang lemah. Demikianlah Allah dalam hakikat-Nya sebagai belaskasih berpihak kepada kehidupan khususnya yang miskin dan lemah. Dalam hakikat diri Allah yang adalah belaskasih itulah manusia menemukan pengharapan yang nyata akan kehidupan. Belaskasih Allah sungguh bagaikan rahim yang menjadi sumber kehidupan manusia. ${ }^{36}$

Belaskasih sebagai hakikat Allah itu memuncak dalam diri Yesus Kristus. Yesus Kristus menganugerahkan arti definitif belaskasih Allah pada seluruh tradisi Perjanjian Lama. Yesus Kristus tidak hanya berbicara tentang belaskasih dan menjelaskan artinya melalui perbandingan dan perumpamaan, tetapi terutama Ia sendiri membuat belaskasih Allah menjelma dan terpersonifikasikan. Paus Fransiskus dalam bulla Misericordiae Vultus (Wajah Kerahiman) mengungkapkan

\footnotetext{
35 S. Leks, Devosan Kerahiman Ilabi Bertanya (Yogyakarta: Kanisius, 2014), hlm. 170; T.E. Feretheim, The Suffering of God: An Old Testament Perspective (Philadelphia: Fortress Press, 1984), hlm. 25; M. Sopocko, The Merry of God in His Works (Stockbridge: Marian Fathers, 1962), hlm. 10.

${ }^{36}$ W. Kasper, Belas Kasih..., hlm. 91.
} 
bahwa Yesus Kristus adalah wajah belaskasih Bapa. Belaskasih Allah yang telah diwahyukan oleh Allah sendiri pada Kel 34:6-7 berlangsung dalam seluruh sejarah bangsa Israel dan memuncak dalam diri Yesus Kristus. Pribadi Yesus Kristus semata-mata hanyalah menunjukkan belaskasih Allah. Apapun yang menggerakkan Yesus dalam semua situasi tidak lain adalah belaskasih Allah, yang dengannya Ia membaca hati orang-orang yang dijumpai-Nya dan menanggapi kebutuhan terdalam mereka. Dengan perumpamaan tentang anak yang hilang yang diajarkan oleh-Nya, Yesus menyatakan sifat Allah sebagai Bapa yang senantiasa mengampuni anak-Nya yang bersalah dan mengatasi penolakan dengan belaskasih. Akhirnya puncak tertinggi dari perwujudan belaskasih Allah dalam diri Yesus terletak pada wafat dan kebangkitanNya. $^{37}$

Belaskasih sebagai hakikat Allah seperti diwahyukan dalam Kel 34:5-7 menjadi nyata dalam seluruh sejarah keselamatan manusia baik pada Perjanjian Lama maupun Perjanjian Baru. Dengan demikian pernyataan ini telah menyangkal apa yang dikemukakan oleh Marcion bahwa Allah Perjanjian Lama adalah Allah yang kejam sedangkan Allah Perjanjian Baru adalah Allah yang berbelaskasih. Sesungguhnya hakikat Allah Perjanjian Lama adalah sama dengan Allah Perjanjian Baru, yaitu belaskasih. Gambaran biblis akan belaskasih Allah bukanlah hal yang baru terwahyukan dalam Perjanjian Baru sebab Perjanjian Lama pun mengandung kekayaan akan belaskasih Allah itu. ${ }^{38}$

\footnotetext{
${ }^{37}$ Paus Yohanes Paulus II, Ensiklik Dives in Misericordia (Kaya dalam Kerahiman) penerjemah A.S. Suhardi (Jakarta: Dokumentasi dan Penerangan KWI, 2016), no.2,8. Selanjutnya dokumen ini disingkat dengan DM diikuti nomor; Paus Fransiskus, Bulla Pemberitabuan Yubileum Luar Biasa Kerabiman Misericordiae Vultus (Wajab Kerabiman) penerjemah F.X. Adisusanto (Jakarta: Dokumentasi dan Penerangan KWI, 2016), no.1,9. Selanjutnya dokumen ini disingkat dengan MV diikuti nomor.

38 Marcion berasal dari kota Sinope yang terletak di pantai selatan Laut Hitam. Ayahnya, uskup kota Sinope, mengucilkannya, karena menurut Epifanius, Marcion memperkosa seorang wanita. Menurut sumber lain alasan pengucilannya ialah kontroversi dogmatis. Sekitar tahun 139, Marcion tiba di Roma dan diterima dalam komunitas Kristen dan kemudian dikucilkan pada bulan Juli 144 karena ajarannya yang sesat (bidaah). Kesalahan teologisnya berasal dari dilema doktrinal dan keyakinan yang tampaknya ortodoks, yaitu bagaimana mungkin Allah yang berbelaskasih sebagaimana diwartakan oleh Yesus Kristus adalah identik dengan Allah yang adil dan menaruh dendam yang ada dalam Perjanjian Lama. Ia menolak mengidentikkan Allah Perjanjian Lama dan Perjanjian Baru. Bahkan ia
} 


\section{Belaskasih sebagai Tanda Kemuliaan, Kemahakuasaan dan Kedaulatan Allah}

Musa meminta agar Allah menunjukkan kemuliaan-Nya kepada dirinya (Kel 33:18). Allah menanggapi permintaan itu dengan menjanjikan "kebaikan-Nya" yang kemudian dipenuhi-Nya dalam pewahyuan nama-Nya pada Kel 34:5-7. Dalam pewahyuan nama-Nya itu Allah menyatakan bahwa hakikat diri-Nya adalah belaskasih. Dengan demikian nampaklah bahwa kemuliaan Allah sesunguhnya nyata dalam belaskasih-Nya. ${ }^{39}$

Kitab Keluaran mengisahkan bahwa kemuliaan Allah dialami oleh bangsa Israel dalam tindakan-Nya yang membebaskan mereka dari perbudakan di Mesir (Kel 9:16; 14:4,18). Dalam peristiwa pembebasan itu Allah menyatakan kemuliaan-Nya dengan mengeraskan hati Firaun dan orang-orang Mesir. Dengan tindakan itu Allah ingin menyatakan kemuliaan-Nya dalam kekuatan-Nya dan tanda-tanda ajaib yang diperbuat-Nya. Kemuliaan Allah juga ditampilkan dalam tanda-tanda yang menakjubkan di padang gurun, yaitu dalam bentuk tiang awan dan tiang api yang menuntun bangsa Israel melintasi padang gurun. Kemuliaan Allah itu pun dialami oleh Musa pada saat penampakan-Nya di Gunung Sinai, yaitu dalam bentuk api yang bernyala-nyala (Kel 24:17). Sedangkan dalam Kel 33:19, Allah menyatakan kemuliaan-Nya dalam kebaikan yang adalah hakikat-Nya. Dengan ini Allah ingin

menolak Perjanjian Lama dan ayat-ayatnya yang merujuk pada Kitab Suci orang Ibrani. Kitab Suci yang diakui Marcion hanyalah Injil Lukas dan Surat-surat Paulus (kecuali Suratsurat Pastoral dan Surat kepada Orang Ibrani). Marcion mendirikan gerejanya sendiri, yang menurut Yustinus, sepuluh tahun kemudian menyebar ke mana-mana hingga abad ke-5. Marcion meninggal sekitar tahun 60. [Lihat Sihol Situmorang, Patrologi: Studi tentang BapaBapa Gereja (Pematangsiantar: STFT St. Yohanes, [tanpa tahun terbit]), hlm. 30-31; T. Krispurwarna Cahyadi, Yohanes Paulus II: Gereja, Teologi, dan Kehidupan (Jakarta: Obor, 2007), hlm. 76 bdk. W. Kasper, Belas Kasih..., hlm. 136.

39 M. Widmer, Moses God and the Dynamics of Intercessory Prayer (Durham: University of Durham, 2003), hlm. 110-111. 
menyatakan bahwa kemuliaan-Nya bukan terutama ditunjukkan dalam hal-hal yang menakjubkan melainkan dalam belaskasih-Nya. ${ }^{40}$

Perjanjian Baru meneguhkan apa yang telah dinyatakan dalam Kel 34:6-7, yakni belaskasih sebagai tanda kemuliaan Allah. Belaskasih Allah dalam Perjanjian Baru itu nyata dalam diri Yesus Kristus. Penginjil Yohanes menunjukkan bahwa Yesus sebagai Firman Allah yang telah menjelma menjadi manusia dan menampakkan kemuliaan Allah itu merupakan pemenuhan kasih karunia Allah (Yoh 1:14,17-18). Dalam 2Kor 4:4-6 pun Rasul Paulus menekankan bahwa wajah dan kehidupan Kristus yang merupakan kasih karunia Allah itu adalah wujud dari kemuliaan Allah. ${ }^{41}$

Kemuliaan Allah itulah yang dimengerti sebagai kekuatan dan kemahakuasaan-Nya. Jika belaskasih adalah tanda kemuliaan Allah, maka belaskasih itu pun dapat dimengerti sebagai tanda kemahakuasaan Allah. Allah karena belaskasih-Nya turut merasakan penderitaan manusia, namun dengan turut menderita bukan berarti bahwa Allah tidak lagi mahakuasa. Dengan berbelaskasih bukan berarti bahwa Allah meninggalkan kemahakuasaan-Nya, tetapi sebaliknya justru merupakan dorongan bagi-Nya untuk menunjukkan kemahakuasaan-Nya. Dalam pewahyuan nama-Nya dengan penyebutan "TUHAN, TUHAN," pengulangan kata TUHAN mau menunjukkan bahwa nama yang disampaikan-Nya menyatakan hakikat-Nya yang sejati, yakni TUHAN Allah yang mahakuasa dan berbelaskasih. Dalam salah satu doa kuno juga dikatakan: "Ya Allah, yang menyatakan kekuasaan-Mu terutama dalam belaskasih dan pengampunan-Mu. ${ }^{, 42}$

\footnotetext{
${ }^{40}$ C. Barth, Theologia Perjanjian..., hlm. 144; G.A. Cole, "Exodus 34. The Middoth and the Doctrine of God: The Importance of Biblical Theology to Evangelical Systematic Theology", dalam Southern Baptist Journal of Theology 12/3 (2008), hlm. 27.

${ }^{41}$ P.J. Gentry, "The Glory of God: The Character of God's Being and Way in the World: Some Reflections on A Key Biblical Theology Theme", dalam The Southern Baptist Journal of Theology 20/1 (2016), hlm. 159-160.

${ }^{42}$ W. Eichrodt, Theology of..., hlm. 30. Doa kuno itu diucapkan sebagai Doa Pembuka Minggu Biasa XXVI. Doa tersebut sudah ada pada abad ke-8 dalam Sacramentum Gelasianum (tahun 1198). [Lihat S. Leks, Kompendium Devosi Kerabiman Allah (Yogyakarta: Kanisius, 2016), hlm. 59.]
} 
Selain menunjukkan kemuliaan dan kemahakuasaan-Nya, belaskasih juga menjadi tanda dari Allah yang menyatakan kedaulatanNya. Allah mencurahkan belaskasih-Nya bukan karena hukum yang mengikat diri-Nya, bukan pula karena Ia telah mengikat perjanjian dengan Abraham dan bangsa Israel, tetapi dengan perjanjian itu Allah mau menyatakan kedaulatan-Nya. ${ }^{43}$

Penggalian arkheologis di Asia Kecil telah menemukan naskah perjanjian dari zaman para leluhur Israel yang dapat digunakan untuk memahami perjanjian antara Allah dan bangsa Israel. Naskah-naskah dari hasil penggalian itu menunjukkan adanya perjanjian antara Raja Het sebagai pihak pertama dengan beberapa raja lain yang di bawah kekuasaannya sebagai pihak kedua. Raja-raja bawahan itu berjanji dalam bentuk sumpah bahwa mereka akan tetap patuh kepada Raja Het dan akan mengindahkan hak-hak sang raja. Perjanjian itu merupakan tanda terima kasih dari para raja bawahan kepada Raja Het yang menjadi pelindung mereka. Raja Het sendiri tidak ikut bersumpah, meskipun demikian ia dengan sukarela akan setia melindungi bawahannya. Begitu pula kiranya perjanjian antara Allah dengan para Bapa Bangsa Israel. Allah tanpa sedikitpun mengharapkan balas jasa dari bangsa Israel, namun Ia berjanji akan setia memberikan perlindungan kepada bangsa Israel. Kesetiaan Allah kepada bangsa Israel itulah yang disebut hesed. ${ }^{44}$

Dalam hesed-Nya itu Allah sungguh bebas. Dalam hesed-Nya Allah tidak wajib menolong bangsa Israel, dan Israel pun tidak berhak untuk menuntut pertolongan Allah. Allah memang mengadakan perjanjian, tetapi perjanjian itu tidak membuat-Nya menjadi terikat dan Allah tidak menjadi tahanan atas perjanjian itu, apalagi menjadi tahanan manusia karena Allah mengadakan perjanjian dengan manusia. Dengan demikian nampaklah bahwa sesungguhnya Allah berdaulat dalam menyatakan belaskasih-Nya. Allah tidak tergantung dengan apapun untuk dapat menyatakan belaskasih-Nya. Hal ini menunjukkan bahwa Allah sungguh berbeda dengan dewa-dewi di sekitar bangsa Israel yang mengharapkan kurban dan persembahan demi pengampunan. Allah

${ }^{43}$ C. Barth, Theologia Perjanjian..., hlm. 94.

${ }^{44}$ C. Barth, Theologia Perjanjian..., hlm. 95. 
berbelaskasih kepada manusia bukan karena kurban dan persembahan manusia. Allah sebagai pengasih (hannûn) mencurahkan rahmat-Nya secara gratis kepada bangsa Israel. Keputusan Allah untuk memberikan rahmat-Nya tidak tergantung pada kondisi manusia yang akan menerima rahmat itu melainkan mutlak tergantung kepada-Nya. Belaskasih Allah sungguh tergantung pada diri-Nya sendiri. ${ }^{45}$

\section{Belaskasih sebagai Rahmat Pengampunan atas Pertobatan}

Pewahyuan akan belaskasih Allah dalam Kel 34:6-7 adalah "jalan" yang dimohonkan Musa kepada Allah agar hubungan-Nya dengan bangsa Israel dapat dipulihkan kembali. Dengan pewahyuan diriNya itu Allah memulihkan hubungan-Nya dengan bangsa Israel yang telah rusak karena ulah bangsa itu sendiri. Dengan demikian pengampunan adalah tanda yang paling nampak dari belaskasih Allah. Oleh karena itu, Allah pun menghendaki pertobatan manusia agar tetap hidup dan tidak mati karena dosa. ${ }^{46}$

Belaskasih Allah sedemikian besar sehingga Ia tidak serta-merta menghukum bangsa Israel yang telah berdosa melainkan memberikan waktu untuk kembali bertobat dan memperoleh pengampunan dari-Nya. Belaskasih Allah memang sedemikian besar sehingga Ia begitu sabar, meskipun demikian bukan berarti bahwa murka Allah tidak akan pernah terjadi. Kemurkaan Allah tetap akan berlangsung karena Ia tidak dapat membiarkan dan kompromi dengan dosa. Kesabaran Allah harus dimengerti sebagai kesempatan yang diberikan kepada bangsa Israel untuk bertobat. ${ }^{47}$

Dengan pewahyuan Allah dalam Kel 34:5-7 bangsa Israel didorong untuk kembali kepada Allah dan mohon pengampunan setiap kali berdosa. Kel 34:5-7 mengungkapkan bahwa kemurkaan Allah terjadi hingga empat generasi tetapi belaskasih-Nya dicurahkan kepada beribu-

\footnotetext{
45 C. Barth, Theologia Perjanjian..., hlm. 96; P. Heinisch, Theology of the Old Testament (Minnesota: Liturgical Press, 1955), hlm. 101.

46 R.W.L. Moberly, At the Mountain of God: Story and Theology in Exodus 32-34 (Sheffield: JSOT Press, 1983), hlm. 79; T. Krispurwarna Cahyadi, Kemurahan Hati..., hlm. 42.

${ }^{47}$ J.C. Laney, “God's Self-Revelation...”, hlm. 46.
} 
ribu orang. Artinya, murka Allah hanya berlangsung sementara, sedangkan belaskasih-Nya selama-lama-Nya. Dalam belaskasih Allah seperti itulah bangsa Israel menemukan harapan dan terdorong untuk bertobat. Nah, karena belaskasih Allah itu tak terbatas, maka pengampunan Allah pun senantiasa mengalir tanpa batas. Allah selalu siap mengampuni, dan tidak pernah lelah mengampuni dengan cara-cara yang selalu baru dan menakjubkan. Kuasa pengampunan Allah senantiasa mengalir dan keterbatasannya justru pada manusia. Kurangnya kehendak baik dan tidak adanya kemauan untuk menyesal dan bertobat dari manusialah yang menjadikan belaskasih Allah itu tidak sampai kepadanya. $^{48}$

Sesungguhnya tidak ada dosa manusia yang dapat membatasi kuasa pengampunan Allah sebagaimana dinyatakan dengan tiga istilah dalam Kel 34:7c. Dengan demikian tidak satu pun dosa yang disesali oleh pendosa yang bertobat di hadapan belaskasih Allah dapat dikecualikan dari pelukan pengampunan-Nya. Belaskasih Allah jauh lebih besar dari dosa apapun juga dan jembatan penghubung yang mempersatukan kembali Allah dengan manusia. ${ }^{49}$

Pengampunan yang bersumber dari belaskasih Allah itu secara nyata hadir lewat sakramen-sakramen yang ada dalam Gereja, khususnya Sakramen Ekaristi dan Sakramen Tobat. Dalam Sakramen Ekaristi, pengampunan dosa dicurahkan sebagai rahmat berkat kurban tubuh dan darah Yesus. Dalam Sakramen Tobat, Allah datang menjumpai, memeluk dan menganugerahi rahmat agar si pendosa dapat kembali menjadi putraputri-Nya. Sakramen Tobat adalah pengakuan iman terhadap belaskasih Allah. Sakramen Tobat memperdamaikan kembali manusia dengan Allah dari relasi yang telah rusak akibat dosa manusia sehingga manusia dapat hidup kembali dalam rahmat Allah. ${ }^{50}$

\footnotetext{
${ }^{48} \mathrm{MV}$, no. 21,22,24.

49 Paus Fransiskus, Nama Allah adalah Kerahiman, penerjemah P.A. Heuken (Jakarta: Cipta Loka Caraka, 2016), hlm. 31; MM, no.2; MV, no.2.

50 MM, no.8; W. Kasper, Belas Kasih..., hlm. 242; L. Dihe, Sakramen Tobat di Tengah Globalisasi (Yogyakarta: Kanisius, 2013), hlm. 39,107.
} 


\section{Belaskasih dan Keadilan Allah}

Belaskasih Allah kerap kali sulit dimengerti dalam hubungannya dengan keadilan-Nya. Bapak ilmu skolastik abad pertengahan, St. Anselmus dari Canterbury, mempertanyakan: "Bagaimana Allah dapat dinyatakan berbelaskasih sekaligus adil?" Pewahyuan nama Allah dalam Kel 34:5-7 menunjukkan Allah yang berbelaskasih sekaligus adil. Keadilan-Nya nyata dalam pernyataan bahwa Ia akan menghukum orang yang berbuat salah (Kel 34:7c). Di samping itu keadilan Allah juga dilukiskan dalam Kel 32-34, yakni bahwa Allah menghukum bangsa Israel yang telah melanggar perjanjian dengan-Nya lewat pembunuhan oleh kaum Lewi atas tiga ribu orang Israel (Kel 32:26-28) dan tulah kiriman Allah yang mengakibatkan kematian sejumlah orang Israel (Kel $32: 35) .^{51}$

Kisah tentang Allah yang menghukum manusia karena dosanya sudah tertulis sejak buku pertama dari Kitab Suci. Kej 3 mengisahkan tentang Allah yang menghukum manusia pertama dan istrinya karena dosa ketidaktaatan mereka pada perintah-Nya. Bahkan ular yang tadinya merupakan binatang paling cerdik di antara segala binatang di padang pun dihukum menjadi binatang yang terkutuk karena keterlibatannya dalam kejatuhan manusia ke dalam dosa. Kej 4 melukiskan tentang Allah yang menghukum Kain karena pembunuhan terhadap Habel dengan menjadikannya seorang pengembara dan pelarian di bumi. Kej 6-7 menceritakan tentang Allah yang menjatuhkan hukuman berupa Air Bah kepada manusia yang kecenderungannya membuahkan kejahatan. ${ }^{52}$

Allah menghukum umat-Nya, tetapi hukuman-Nya itu tidak meniadakan belaskasih sebagai hakikat-Nya. Hukuman Allah sebagai wujud keadilan-Nya tidak mengurangi belaskasih-Nya bahkan semakin meneguhkannya. Belaskasih dan hukuman Allah sesungguhnya saling bertalian satu sama lain, bahkan saling melengkapi seperti dua sisi dari satu sikap Allah terhadap umat-Nya. Dalam konteks Kel 32-34, Allah menghukum bangsa Israel agar rencana belaskasih-Nya kepada mereka

\footnotetext{
${ }^{51}$ H.J. Pokrifka-Joe, Divine Mercy..., hlm. 105.

${ }^{52}$ C. Barth, Theologia Perjanjian..., hlm. 65.
} 
sebagai bangsa yang kudus dan kerajaan imam bagi bangsa-bangsa lain semakin nyata. $^{53}$

Hukuman Allah harus dimengerti sebagai peringatan moral yang mengarahkan manusia kepada pertobatan. Hukuman Allah semata-mata dilakukan untuk memperingatkan, mendisiplinkan dan menyucikan bangsa Israel serta mendidik mereka agar lebih taat kepada Allah dan semakin kudus. Hukuman menjadi cara bagi Allah untuk memulihkan perjanjian dan hubungan-Nya dengan manusia yang telah dirusak oleh manusia itu sendiri lewat dosa yang dilakukannya. Hukuman Allah selalu dalam konteks belaskasih-Nya yang menyelamatkan. Oleh karena itu, hukuman yang adalah wujud keadilan Allah harus dimengerti sebagai wujud belaskasih-Nya pula. ${ }^{54}$

Hukuman Allah sesungguhnya adalah bentuk belaskasih-Nya, karena melalui hukuman itu Allah "memukul" perbuatan manusia yang mendatangkan kematian dan kerusakan bagi manusia itu sendiri (Kej 8:21). Dengan hukuman itu Allah memberi tanda peringatan, menghalangi dan bahkan menghentikan rencana jahat manusia. Allah tak membiarkan perbuatan jahat manusia terjadi begitu saja dan membawa kematian baginya sendiri. Maka, hukuman Allah yang mengusir Adam dan Hawa dari taman Eden harus dilihat sebagai tindakan-Nya untuk melindungi manusia dari kemungkinan melakukan pelanggaran yang lebih besar dari sebelumnya. Dengan mengusir mereka dari taman Eden, Allah ingin menghalangi agar manusia jangan masuk lagi ke taman Eden dan mengambil buah pohon kehidupan sehingga akan hidup untuk selama-lamanya (Kej 4:22). Allah justru ingin menghindarkan manusia dari perjuangan hidup yang tidak berkesudahan. Demikian halnya dengan hukuman Allah pada kisah menara Babel (Kej 11). Allah menghalangi rencana orang-orang Babel dengan mengacaukan bahasa untuk menghindarkan mereka dari rencana-rencana yang lebih jahat lagi. ${ }^{55}$

\footnotetext{
${ }^{53}$ H.J. Pokrifka-Joe, Divine Mercy..., hlm. 296.

${ }^{54}$ P. Heinisch, Theology of..., hlm. 94,302; H.J. Pokrifka-Joe, Divine Mercy..., hlm. 296; W. Eichrodt, Theology of..., hlm. 428,437-438,475; T.E. Feretheim, The Suffering of..., hlm. 137; W. Kasper, Belas Kasih..., hlm. 30.

${ }^{55}$ C. Barth, Theologia Perjanjian..., hlm. 65.
} 
Perjanjian Lama memberi kesaksian bahwa justru dalam hukuman Allah yang mendatangkan penderitaan itulah manusia kian merasakan pemeliharaan dari Allah yang berbelaskasih. Bangsa Israel sendiri menyadari bahwa hukuman Allah sesungguhnya merupakan cara Allah untuk membimbing mereka. Oleh karena itu, bangsa Israel tidak hanya meneruskan berita-berita tentang segala pertolongan Allah saja, tetapi juga segala hukuman yang ditimpakan-Nya kepada mereka. Meskipun amat jarang namun terdapat juga bentuk pujian dari bangsa Israel atas hukuman yang diberikan Allah, misalnya Mzm 119:75 “Aku tahu, ya TUHAN, bahwa hukum-hukum-Mu adil, dan bahwa Engkau telah menindas aku dalam kesetiaan. "56

Hukuman Allah tidaklah membinasakan umat-Nya (Yer 10:24). Hukuman yang merupakan wujud belaskasih Allah itu tidak juga tanpa batas. Allah sendiri menetapkan batas bagi hukuman itu. Beratnya hukuman dan lamanya hukuman, semuanya berada dalam tangan Allah dan semuanya itu demi kebaikan manusia itu sendiri. Memang hukuman yang seharusnya ditimpakan kepada manusia tidaklah dapat ditanggung oleh manusia. Dalam Kel 32-34 misalnya, nampak bahwa hukuman yang ditanggung oleh bangsa Israel itu memang jauh lebih ringan dari yang semestinya. Hukuman yang pantas bagi bangsa Israel sesungguhnya adalah kebinasaan sebagaimana dinyatakan oleh Allah sendiri dalam Kel 32. Namun karena belaskasih Allah, hukuman itu dikurangi menjadi pembunuhan oleh kaum Lewi atas tiga ribu orang Israel saja (Kel 32:2628) dan tulah yang dikirimkan Allah hanya mengakibatkan kematian sejumlah orang Israel (Kel 32:35). Dalam Kej 4:13 juga tercatat bagaimana Kain menyadari bahwa hukuman atas kesalahannya sesungguhnya lebih besar dari pada yang dapat ia tanggung (Kej 4:13). ${ }^{57}$

Dari uraian di atas nampak bahwa dalam keadilan, Allah mewujudkan belaskasih-Nya. Belaskasih memang berbeda dengan keadilan, tetapi keduanya tidak berlawanan. Belaskasih Allah harus dikaitkan dengan keadilan-Nya, karena tanpa prinsip keadilan maka belaskasih dapat disalahgunakan. Belaskasih Allah bukanlah suatu

\footnotetext{
${ }^{56}$ C. Barth, Theologia Perjanjian..., hlm. 67,179.

${ }^{57}$ C. Barth, Theologia Perjanjian..., hlm. 66.
} 
rahmat murahan yang membiarkan ketidakadilan terjadi. Belaskasih yang meniadakan keadilan menjadi belaskasih palsu (pseudomercy) dan tak sesuai dengan belaskasih Allah yang sesungguhnya. Belaskasih tidak meniadakan keadilan, tetapi justru menyempurnakan keadilan. Belaskasih tidak berada dalam sikap kompromistis dan tidak berprinsip atau relativistis, yang selanjutnya dapat mengabaikan keadilan Allah. Belaskasih justru tumbuh dari pribadi yang kuat, berprinsip dan tahu menata hidup serta membangun diri dalam jiwa yang besar dan hati yang rela berkorban. Belaskasih tumbuh dalam pribadi yang memegang teguh perjanjian. Keadilan tanpa belaskasih adalah kekejaman. Namun belaskasih tanpa keadilan pun adalah induk kehancuran dan perpecahan. Oleh karena itu, belaskasih dan keadilan harus saling berkaitan satu sama lain. Hal ini mengingatkan pada Kristus yang dalam mewahyukan belaskasih Allah, pada saat yang sama menuntut hidup yang sesuai dengan nilai-nilai Kerajaan Allah. ${ }^{58}$

Dengan berbelaskasih, Allah tidak mengingkari keadilan-Nya, karena keadilan pun adalah hakekat-Nya. Sesungguhnya keadilan Allah bukan sekadar menghukum yang jahat dan mengganjar yang baik, tetapi Allah tetap setia pada hukum yang telah ditetapkan-Nya. Hukum itulah hesed-Nya, yakni Ia tetap setia pada janji-Nya kepada manusia. Namun hesed bukan berarti bahwa Allah seolah-olah seorang hakim yang terdorong oleh rasa kasihan sehingga tidak melakukan apa yang ditetapkan oleh hukum. Hesed Allah adalah kesetiaan-Nya yang tetap akan mencurahkan belaskasih-Nya. Inilah keadilan Allah yang sesungguhnya. Allah menyelubungi dan mengatasi keadilan-Nya dengan peristiwa yang bahkan lebih besar, yang membuat manusia mengalami belaskasih sebagai dasar keadilan sejati. ${ }^{59}$

Dalam diri Yesus Kristus nampak jelas keselarasan antara belaskasih dan keadilan Allah tersebut. Yesus yang begitu berbelaskasih tetap menuntut adanya pertobatan dari manusia sebab setiap orang pada akhirnya akan diadili atas perbuatannya masing-masing (bdk. Mat 13:3643,47-52; 25:31-46). Selain dalam pengajaran-Nya lewat perumpamaan,

\footnotetext{
${ }^{58}$ DM, no.4; W. Kasper, Belas Kasih..., hlm. 111,221,264.

${ }^{59} \mathrm{MV}$, no.21.
} 
Yesus juga menunjukkan keselarasan antara belaskasih dan keadilan itu dalam tindakan-Nya. Injil mengisahkan bahwa setiap kali mengampuni orang berdosa, Yesus selalu berpesan agar orang itu tidak melakukan kesalahan yang sama lagi. Yesus memberi pengampunan sekaligus menuntut pertobatan dari si pendosa. Salah satu contohnya, kisah tentang Yesus yang mengampuni seorang perempuan yang kedapatan berbuat zinah dalam Yoh 7:53-8:11. Yesus mengampuni dan tidak merajam wanita itu meskipun sebenarnya Ia berhak atas hal itu. Dalam belaskasihNya, Yesus memberikan pengampunan dan kebebasan bagi wanita itu, namun Yesus juga berpesan agar perempuan itu tidak lagi melakukan kesalahan yang sama (Yoh 8:11). Dengan demikian Yesus menunjukkan bahwa Ia sungguh berbelaskasih sekaligus adil. ${ }^{60}$

\section{Penutup}

Sebagai umat Kristen, kita diundang untuk mengalami dan diutus untuk mewartakan belaskasih Allah. Kita mengemban tugas untuk memprioritaskan pewartaan belaskasih Allah, karena belaskasih adalah hakikat Allah dan intisari hidup Injili. Namun jangan sampai kita keliru mewartakan belaskasih Allah itu dengan meniadakan keadilan-Nya. Belaskasih Allah tetap menuntut agar manusia melaksanakan perintahperintah-Nya, karena Ia tetap akan menghukum yang bersalah. Oleh karena itu, belaskasih Allah tak boleh dipertentangkan dengan keadilanNya. Belaskasih Allah juga tak boleh disalahgunakan untuk melanggar nilai-nilai etos Kristiani. Misalnya, dengan dalih belaskasih Allah yang tanpa batas kita mati-matian melindungi si pelaku kejahatan dari pada membela si korban yang tak bersalah; karena alasan belaskasih Allah yang begitu besar kita pasang badan menolak segala usaha pembongkaran kasus penyelewengan dalam institusi Gereja, tarekat religius atau perkumpulan apa pun. Belaskasih Allah pun tak boleh disalahartikan sebagai sikap pembiaran terhadap perilaku yang salah dan

${ }^{60}$ S. Surip, Akhir Zaman: Kata-kata Masyal Bermoral (Yogyakarta: Kanisius, 2013), hlm. 126; S. Dew, "Go and Sin No More: Christian Mercy vs Tabloid Vengeance", dalam CJM 52 (Summer: 2003), hlm. 4-5. 
"rahmat murahan" seperti pewartaan pengampunan Allah tanpa tuntutan penyesalan dan pertobatan. ${ }^{61}$

Pengampunan adalah tanda nyata belaskasih Allah, tetapi kenyataannya penerimaan Sakramen Tobat kurang diminati banyak umat. Oleh karena itu, kita harus berjuang menggiatkan penerimaan Sakramen Tobat, agar belaskasih Allah semakin dialami oleh banyak orang di zaman ini terutama mereka yang merasa tidak berdosa. Salah satu faktor penyebab meningkatnya perasaan tak berdosa adalah gaya hidup konsumtif $^{62}$ dan hedonis. ${ }^{63}$ Orang yang bergaya hidup konsumtif dan hedonis akan merasa hidupnya sudah sangat berarti bila sudah mendapatkan kepuasan dalam hal-hal duniawi, sehingga lambat laun kepuasan diri itu akan mengikis dan melunturkan rasa berdosa dalam dirinya. Di samping itu disinyalir pula bahwa efek negatif dari kemajuan cara berpikir dan pendidikan di zaman ini, telah membuat orang semakin rasional dan dalam arti tertentu mudah kehilangan rasa berdosa karena orang merasionalisasikan setiap perbuatannya. Alhasil, tidak menyadari dan mengakui diri sebagai pendosa sama artinya dengan tidak memerlukan belaskasih Allah. ${ }^{64}$

Kita mengemban tugas untuk menceritakan belaskasih Allah sebagaimana diajarkan dalam Perjanjian Lama maupun Perjanjian Baru kepada dunia zaman ini. Khususnya bagi para pengkhotbah, belaskasih Allah harus diwartakan secara relevan, yaitu dengan memperhatikan

\footnotetext{
${ }^{61}$ W. Kasper, Belas Kasih..., hlm. 220,260; MV, no.21.

62 Gaya hidup konsumtif adalah gaya hidup boros dan berlebihan yang lebih mendahulukan keinginan dari pada kebutuhan dan tidak ada skala prioritas, sehingga gaya hidup ini juga disebut gaya hidup yang suka bermewah-mewah. Orang yang bergaya hidup konsumtif tidak lagi mempertimbangkan fungsi atau kegunaan ketika membeli barang, melainkan mempertimbangkan prestise yang melekat pada barang tersebut. [Lihat L. Dihe, Sakramen Tobat..., hlm. 77.]

${ }^{63}$ Kata hedonis berasal dari kata Yunani hèdonismos dengan akar katanya bèdonè yang artinya "kesenangan." Penganut hedonis yakin bahwa segala sesuatu dianggap baik bila dapat memuaskan keinginan manusia dan meningkatkan kesenangan dirinya. Berdasarkan akar kata tersebut dapat dikembangkan pengertian bedonisme sebagai pandangan hidup yang menganggap bahwa kesenangan dan kenikmatan materi adalah tujuan utama hidup ini. [Lihat L. Dihe, Sakramen Tobat..., hlm. 84.]

64 W. Kasper, Belas Kasih..., hlm. 244-245; L. Dihe, Sakramen Tobat..., hlm. 89; E. Martasudjita, Sakramen-Sakramen Gereja: Tinjanan Teologis, Liturgis, Pastoral (Yogyakarta: Kanisius, 2003), hlm. 327-328; Paus Fransiskus, Nama Allah..., hlm. 40.
} 
situasi konkret umat dan menolong mereka memaknai belaskasih Allah itu dalam kehidupan sehari-hari. Seorang pengkhotbah pun hendaknya lebih dahulu berusaha mengalami dan menghidupi secara pribadi belaskasih Allah itu, sehingga khotbah-kotbahnya akan semakin dijiwai oleh belaskasih Allah dan dapat menuntun banyak orang untuk menghidupinya. ${ }^{65}$

Dalam rangka mengalami, menghidupi dan mewartakan belaskasih Allah itu Paus Fransiskus telah menunjukkan bahwa pewartaan belaskasih Allah tidaklah menutup kemungkinan untuk menegur para pelaku kejahatan. Hal ini nampak secara khusus dalam bulla Misericordiae Vultus (Wajah Kerahiman). Dalam bulla yang berbicara mengenai belaskasih Allah itu Paus menegur para pelaku kriminal dan koruptor. Teguran itu tidak bertentangan dengan pewartaan belaskasih, tetapi justru mengungkapkan ajakan bagi mereka untuk mengalami belaskasih Allah. ${ }^{66}$

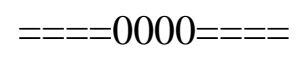

\footnotetext{
${ }^{65}$ MM, no.6; W. Kasper, Belas Kasih..., hlm. 237.

${ }^{66} \mathrm{MV}$, no.19.
} 


\section{DAFTAR PUSTAKA}

Barth, C. Theologia Perjanjian Lama 1. Jakarta: BPK Gunung Mulia, 2015.

Brueggemann, W. Theology of the Old Testament. Minneapolis: Fortress Press, 1997.

Casuto, U. A Commentary on the Book of Exodus. Yerusalem: Magnes Press, 1967.

Clements, R. The Cambridge Bible Commentary on the New English Bible: Exodus. Cambridge: Cambridge University Press, 1972.

Cole, A. Exodus: An Introduction and Commentary. London: Tyndale Press, 1973.

Deden. Pertjikan Alkitab: Tjinta Kasih Allah. Penerjemah I. Sutardja. Ende: Flores, 1969.

Dihe, L. Sakramen Tobat di Tengah Globalisasi. Yogyakarta: Kanisius, 2013.

Durham, J.J. Exodus. WBC 3. Waco: Word Books, 1987.

Eichrodt, W. Theology of the Old Testament. 2 jilid. London: SCM Press, $1961 / 1967$.

Feretheim, T.E. The Suffering of God: An Old Testament Perspective. Philadelphia: Fortress Press, 1984.

Heinisch, P. Theology of the Old Testament. Minnesota: Liturgical Press, 1955.

Kasper, W. Belas Kasih Allah: Dasar Kitab Suci dan Kunci Hidup Kristiani. Penerjemah F.X. Hadisumarta. Malang: Karmelindo, 2016. 
Krispurwarna Cahyadi, T. Kemurahan Hati: Wajah Allah-Kesaksian Gereja. Yogyakarta: Kanisius, 2016.

Laney, J.C. "God's Self-Revelation in Exodus 34:6-8", dalam Bibliotheca Sacra 158 (Januari-Maret 2001), hlm. 36-51.

Moberly, R.W.L. At the Mountain of God: Story and Theology in Exodus 32-34. Sheffield: JSOT Press, 1983.

Paus Fransiskus. Bulla Pemberitahuan Yubileum Luar Biasa Kerahiman Misericordiae Vultus (Wajah Kerahiman). Penerjemah F.X. Adisusanto. Jakarta: Dokumentasi dan Penerangan KWI, 2016.

. Nama Allah adalah Kerahiman. Penerjemah P.A. Heuken. Jakarta: Cipta Loka Caraka, 2016.

. Surat Apostolik Paus Fransiskus pada Penutupan Yubileum Luar Biasa Kerahiman Misericordia et Misera (Belaskasih dan Penderitaan). Penerjemah F.X. Adi Susanto. Jakarta: Dokumentasi dan Penerangan KWI, 2017.

Paus Yohanes Paulus II. Ensiklik Dives in Misericordia (Kaya dalam Kerahiman). Penerjemah A.S. Suhardi. Jakarta: Dokumentasi dan Penerangan KWI, 2016.

Pokrifka-Joe, H.J. Divine Mercy and Judgment in Exodus 34:6-7 and A Selection of Its Echoes. Skotlandia: University of St. Andrews, 2004. (Disertasi).

Stoebe, H.J. "hesed", dalam Jenni, E. dan Westermann, C. (eds.), Theological of the Old Testament. Massachusetts: Hendrickson Publishers, 1997.

Surip, S. Kitab Taurat Musa: Pengantar dan Tafsir Pilihan Kitab Kejadian, Kitab Keluaran, Kitab Imamat, Kitab Bilangan, Kitab Ulangan. Pematangsiantar: [tanpa penerbit], 2017. (Diktat). 
Lagas, Jurnal Filsafat-7ealogi, Val. 17, Na. 2. Juni 2020

- Tragedi Kemanusiaan. Kejatuhan, Peradaban Jahat, dan Penderitaan Manusia. Yogyakarta: Kanisius, 2008. 